\title{
Constrained choices, enhanced aspirations: Transnational mobility, poverty and development. A case study from North Hungary ${ }^{1}$
}

\author{
Judit Durst - Zsanna Nyíró \\ https://doi.org/10.51624/SzocSzemle.2018.4.1 \\ Manuscript received: 11September 2018. \\ Modified manuscript received: 19 December 2018. \\ Acceptance of manuscript for publication: 21 December 2018.
}

\begin{abstract}
This paper aims to contribute to the exploration of the nexus of poverty, migration and development by providing what has been lacking thus far; namely, a close ethnographic portrait, combined with a survey, that interprets the most typical and diverging migration trajectories and their impacts in an economically backward and ethnically differentiated region in Hungary. Building on the inspirational work of anthropologists and mobility scholars who propose to recover a global and multidimensional perspective on transnational movement when exploring the nexus between migration and its consequences for development, we carried out multi-sited ethnography, both in the sending and in the destination localities. We also conducted a survey among migrants who had returned, sometimes temporarily, to their community of origin. Using this multi-spatial approach, we demonstrate the different layers of the migration-development nexus. We argue that, on the global level, receiving countries all benefit from the cheap and flexible labor of poor migrants, be they Roma or non-Roma, skilled or low-skilled mobile laborers. However, on the level of migrant-sending localities, due to the differential migration patterns of local Roma and non-Roma, the developmental effects of the two groups' geographical movement cannot be taken as homogeneous or leveled. For non-Roma families, when men leave behind their wives and children for the sake of financial betterment of their family, there is little developmental effect on community level, but only in a narrow financial sense. However, we argue, drawing on Appadurai's (2004) "capacity to aspire" concept, that for a fraction of some kinship groups of low-skilled Roma who mainly migrate with their whole family, transnational mobility may not be as successful financially as for the non-Roma, although it has future-oriented developmental elements by potentially enhancing capacity to aspire for both migrants and non-migrants.
\end{abstract}

Keywords: Transnational mobility, migration and development nexus, poverty, capacity to aspire, poor Roma and non-Roma Hungarian migrants

1 Part of the research that produced the empirical material for this paper was supported by a research grant from the Hungarian Academy of Science, NKFIH (K 111 969), entitled "Outmigration from Hungary and its effect on rural societies." The empirical findings in this paper result from the ethnographic fieldwork and narrative interviews conducted by the first author. The analyses of the survey data are the work of the second author.

We wish to thank our two anonymous reviewers for their inspiring critical comments on the first draft of the manuscript. We are indebted to Endre Sik who helped us restructure our survey findings. Thanks also go to Krisztina Németh and Eszter Berényi for their patience and valuable contributions to the final version of this paper. Finally, special thanks go to our Roma friends and research assistants, and the hosting families who made this research possible by opening their homes to us in Peteri, Toronto, and in England, and who let us take part in their everyday lives. 


\section{Introduction}

"The outmigration from Peteri is not significant," said the mayor of Peteri, a small town of almost 10,000 inhabitants in the economically backward region of North Hungary, to us in the Fall of 2013 when we began our ethnographic fieldwork. He tried to convince us that his town was not the best site for our research as there was not much outmigration from there. By then, half of the inhabitants of the Roma settlement (a segregated neighbourhood on the outskirts of the town with almost 3000 dwellers) had left for Toronto, Canada, and when having been deported or after returning from there, they went on to England.

Although the Hungarians were for long less mobile than their Eastern-Central European neighbors, by 2010 they had "matured for migration" (Sik 2013) according to national surveys measuring the migration potential of the population. Recently, public discourse and academics in Hungary have begun to speak about an "exodus". Since 2010, 500-600,000 Hungarians have left the country to work abroad in the free EU labour market or in North America (Hárs 2016, 2018).

The Roma, the biggest, most discriminated against and socially and economically disadvantaged minority in Hungary, have joined this migration process - although their destination countries are somewhat different (Kováts 2002, Vidra 2013, Blaskó - Gödri 2014, 2016, Vidra - Virág 2013, Durst 2013, Moreh 2014).

There is very little research about the outcome of this nationwide migration process, mainly due to its relatively new development (for the few exceptions, see Váradi 2018, Virág 2018, Németh-Váradi 2018, this volume). We have even less knowledge about the almost "invisible" cross-border mobility of poor people with low educational attainment. These migrants seem to be invisible not only in the context of national survey results in Hungary - according to which the young, educated and professionally or vocationally qualified part of the Hungarian population make up most of the country's emigrants (Blaskó - Gödri 2014, 2016, Hárs 2018) - but their movement has remained broadly unrecognized also by local governments.

The non-Roma Hungarian mayor of Peteri, the "field" of our case study, only knows of a few families from the Roma settlement who tried to migrate to Canada. He does not have first-hand experience about this process however, as he rarely enters the segregated neighborhoods of his town. On the other hand, he has more contact with local Hungarian families. "Unlike these few Roma, Hungarians do not migrate," he said to us, "in their families it is only the men who go to work abroad to support their families back home in Peteri."

2 All the original names of both settlements and individuals used in this paper have been modified because of the sensitivity of the topic. When referring to local communities, both in Peteri and its neighbouring villages or small towns, we use the terminology employed by the locals themselves. In this region where there is a strong binary social order between the Roma and non-Roma population, those who are labeled as Roma according to the politically correct language used throughout the European Union refer to themselves as Gypsies (Cigány), and everybody else - that is, non-Gypsies (Gadzso) - as Hungarian (Magyar). The distinction between the categories "Gypsy" and (non-Gypsy) „Hungarian" has until now been one of the main rules governing interaction and determining social position in rural societies such as Peteri in Hungary (Horváth 2012, Kovai 2018). 
Meanwhile the working abroad of Hungarians was seen as a (financially) successful process by the mayor, the migration of the Roma has proved to be an unsuccessful story from his perception.

After a year or two, or sometimes three, the Roma families all came back to Peteri. And what did they bring home with them? Nothing. The only thing they managed to achieve with this migration is that their children missed one or two, or sometimes three years of schooling. Because even if they went to school in Canada, they came home knowing nothing. So, we must put them back in the class that they were in when they left. For example, if a child left our school after finishing Year $5^{3}$ and went with her family to Canada, on her return, let's say after three years, we have to put her back in Year 6 among twelve-yearold pupils, even if she is 15 (years old). It gives our teachers a lot of headaches teaching these overage children... The Hungarians are more forward thinking. In Hungarian families it is only the father who goes abroad, mainly to Germany to work. The mother stays behind with the children. In this way, the educational paths of these kids do not get interrupted.

Since 2011 and the beginning of mass out-migration from Hungary, hundreds of families or members of families of inhabitants of Peteri have experienced workrelated, trans-national or rather trans-regional (Sik - Szeitl 2015) mobility. During our ethnographic fieldwork, we realized that we were looking at a "migration-rich community" (Pantea 2013) where people have regularly practised various modes of 'recurring' (Limmer et al. 2010) spatial, cross-border mobility during the last ten years with the aim of generating income when opportunities were scarce in the local labour market (Durst 2018). Even the poor with a low (primary) level of schooling and no command of foreign languages of whom textbooks and courses on migration studies speak of as "resourceless" in terms of migration (Castles - Miller 2009, Melegh - Sárosi 2015), have begun to exercise mobility: mostly trans-regionally (mainly to three destination countries) across national borders. Whether these local types of "migration" - or rather call it trans-regional mobilities - have spurred any development or social transformation in the sending community or at least on the individual level of the return migrants and their households is the main question addressed in this paper.

The topic of the relationship between international migration and its effect on the development of the sending, mostly underdeveloped countries (the so-called migration-development nexus or pendulum; Faist 2008, de Haas 2005) has recently attracted significant attention once again from anthropologists and scholars of migration and development studies. There are two main, opposing theses about the direction and nature of the migration and development nexus - although many scholars have recently drawn attention to the multi-layered, multi-level and multi-

3 As children mainly start primary school in Hungary at the age of six in Year 1, by Year 5 they are 11 years old. 
directional nature of the relationship (Glick Schiller 2009, Faist 2009, Delgado Wise - Covarrubias 2009). Following de Haas's (2008) review, on the one hand there is "developmental pessimism": scholars who represent world systems theory (Wallerstein 1980) and segmented labour market theory (Piore 1979) argue that migration which is shaped by structural economic and power inequalities within and between societies tends to reproduce these inequalities. These theories focus on "how the powerful oppress the poor and vulnerable" (de Haas 2008:15). Some empirical findings from South-East Europe have argued for the usefulness of these theoretical framework by presenting empirical evidence of large-scale depopulation caused by mass outmigration from certain regions of underdeveloped, peripheral or semiperipheral countries such as Romania (Horváth - Kiss 2015). Some of these studies, following Bauman (2004), also speak about the predicament of the "disposable mass of global capitalism," among them poor Roma migrants who cannot be considered "transnational subjects... what they have is their sheer labour, that is the raw material that the peripheral countries offer to core states at [a] low price" (Szabó 2018: 223).

On the other hand, in the analysis of the migration-development nexus there is the so-called "developmental optimism" (Skeldon 1997, Kapur 2004), which has significant support from policy-making proponents among the powerful international financial organizations such as the World Bank, and among myriad non-governmental institutions. This developmental optimism celebrates migrants as development agents through the remittances (financial and social) they send home to their "left behind" family members. In this discourse migrants are portrayed as achieving high social status not only through their remittances but also when they return, due to their conspicuous consumption and their construction of big, fancy new houses - the latter being the most common cross-cultural sign of status improvement (Grigolini 2005, Tesar 2016, Toma et al. 2017). This discourse puts emphasis not only on financial returns but also on so-called "social remittances" (Lewitt 1998): the new values, ideas, practices, identities, and knowledge that migrants transfer in the transnational space (Glick Schiller 2009) which connect them to those in their networks who have stayed home. In the optimistic discourse these remittances are thought to be universal and to have a "levelled" positive effect on the social and political development in the sending localities.

There are scholars, however, especially those working in ethnically mixed communities in peripheral or semi-peripheral, post-socialist countries, who draw attention to a differentiated migration-developmental nexus that focuses on social differentiation and the social closure in localities of origin (Anghel 2016, Toma et al. 2017, Toma - Fosztó 2018, this issue). They argue for the need to dissect the consequences of transnational mobility for social transformation and inequality regarding different local returned migrant groups with diverging mobility patterns, even within single localities (Anghel 2016, Faist 2016). Following this line of thinking, Faist (2016: 389) states that the social mechanism of the partial exclusion 
of poor return migrants of stigmatized minority background (such as the Roma) is an "antidote to optimistic developmental ideas in the wake of post-1989 migration from Central Eastern Europe."

In this paper, we aim to interrogate both leveled developmental pessimism and optimism and test the validity of differential migration-development interactions in the case of our ethnically mixed settlement. With our survey we explore whether there are significant differences in the migration and remittance-sending patterns of the different local ethnic groups. Through our ethnographic case studies we look behind the survey data and analyse whether the differential mobility trajectories of migrants of diverging social characteristics - that is, of Roma and non-Roma, unskilled and skilled laborers - lead to different developmental effects on the level of individual, household and sending locality.

To address these issues, in the following we first discuss the theoretical framework that we found useful for embedding and explaining our empirical findings. Second, we briefly describe our mixed research methodology, and give an introduction to the research setting, delineating the most typical, socially patterned migration trajectories from the town. Then we present our survey results, followed by the ethnographic findings. Here we use the two locally most typical migration trajectories - those of a Roma kinship group and non-Roma guest workers - as ethnographic cases to explain, supplement, and look behind the survey results. Finally, we conclude the article by analyzing the multilevel consequences of migration from the sending locality.

\section{Theoretical Framework}

\section{Poverty, development and the capacity to aspire}

Poverty is partly a "matter of operating with extremely weak resources where the terms of recognition are concerned" (Appadurai 2004: 66). For policy makers and development experts, poverty is usually associated with powerlessness, vulnerability and, above all, a failure of aspirations (Ibrahim 2011). Aspirations literally mean "hopes or ambitions to achieve something." An aspiration is defined as "the perceived importance or necessity of goals" (Copestake - Camfield 2010, cited by Ibrahim 2011: 3). For anthropologists, aspirations are seen as part of wider ethical and metaphysical ideas derived from cultural norms: "Aspirations [for] the good life are part of some sort of system of ideas... which locate them in a larger map of local ideas and beliefs"; however, they "often emerge as specific wants and choices" (Appadurai 2004:68). For many poor people, the aspiration and choice to migrate represents a central component of livelihood strategies (Kothari 2002).

Using Sen's (1999) concept of development, according to which development is an increase in freedom (operationalized as capability) that allows people to lead the lives they aspire to, and accepting de Haas's (2005) conceptualization of human mobility as people's capability (freedom) to choose where to live within broader structural 
constraints, then we conclude that an increase in the capability for mobility itself is a part of development (de Haas 2008). As poverty scholars have pointed out, the failure of poor people to achieve their aspirations can lead to a downward spiral and intergenerational transmission, the latter reflecting the failure of many parents in poor communities to fulfil the aspirations of their children (Ibrahim 2011). Therefore, some poverty studies suggest, building on Sen's (1999) and Appadurai's (2004) work, that development should be perceived as a cognitive process (Copestake - Camfield 2010).

Poverty scholars have also drawn attention to the issue of the formation of aspiration. Ray (2006) speaks about the concept of the aspiration window and aspiration gap. The former means the individual's cognitive world and what $\mathrm{s} / \mathrm{h}$ e views as attainable, while the latter is the distance between what an individual might aspire to and the conditions s/he finds herself in. Ray argues that aspirations are usually inspired by the lives of similar people or role models within the aspiration window.

According to Appadurai, an important part of development is the empowerment of the poor. Empowerment can be translated as increasing the capacity of the poor to aspire. Appadurai defines the concept of the capacity to aspire as a navigational and cultural capacity of a group, which concerns "how a group (and the individuals in it) succeed in reducing the costs of developing a culture of aspirations by envisioning their future, and their capacity to share this future, through... influencing factors in their physical and social environment" (Appadurai 2004: 59). He goes on to argue that "in strengthening the capacity to aspire..., especially among the poor, the future-oriented logic of development could find a natural ally, and the poor could find the resources required to contest and alter the conditions of their own poverty" (Appadurai 2004: 60). Converging on this line of thinking, recent attempts have been made to theorize migration in the aspirations-capabilities (Sen 1999) framework and conceive of migration as a contextualized social process, and an intrinsic part of global change, social transformation, and development (de Haas 2014). This conceptualizes

migration as a "function of aspirations and capabilities to move within a given set of opportunity structures" (de Haas 2014).

\section{Migration, social transformation and the new global labour regime}

During the last two decades, the set of opportunity structures for migration has significantly changed. It is a commonly accepted statement that migration is a part and consequence of social transformation (Castles 2010, Portes 2010, de Haas 2010). One part of social transformation that migration processes are embedded in is the restructuring of the global labour market in highly developed countries through economic deregulation and new employment practices such as subcontracting, temporary employment, and casual work (Castles 2010). On the one hand, the search for competitiveness in a globalized economy, combined with demographic change (the aging population in the developed West), are leading to significant demand for flexible and cheap migrant labour. As Glick Schiller (2009) argues, a new, neoliberal 
labour regime has been developed. Migrant labour, which is increasingly contractual, meets the need of localized neoliberal restructuring - in the form of "flexible and politically silenced" labor (Glick Schiller 2009: 15).

On the other hand, in less developed countries such as many post-socialist Central-Eastern European (CEE) states like Hungary, the social transformation of the labour market (that is, the massive loss of jobs due to structural changes, including the closing down of industrial factories) further encourages outmigration of "superfluous" former socialist workers (Melegh et al. 2018, this issue), among them the currently unemployed, low-skilled Roma, in search of better lives and livelihoods. These changes in the globalized labour market have fostered new streams of mobility in the direction of the developed Western European countries since the $2004 \mathrm{EU}$ accession, which provided legal rights for residence and work to the newly accepted EU Member States' citizens. However, while the European political establishment celebrates the free movement of goods, people and ideas in the space of the European Union, the mobility regimes of the Member States are rather selective in terms of how they welcome highly educated professionals (the "global talents") but criminalize and hinder the mobility of the poor (Glick Schiller - Salazar 2013). One contradiction in migration-development studies is that while migrant remittances are welcomed and defined as vital resources for poverty reduction, those who send remittances are denigrated as a social threat (Glick Schiller 2009).

This is particularly true in the case of the Central Eastern European poor, lowskilled and especially Roma migrants. Scholars from different disciplines who have analyzed the transnational mobilities of precarious Roma networks emphasize the un/free (blocked or impeded) character of their geographical movement (Yildiz -de Genova 2017, Van Baar 2017, Nagy 2016, Greenfields - Dagilyte 2018, Sardelic 2017, Humphris 2017). Many Hungarian Roma migrants, however, are outsmarting the selective mobility regime (Nagy - Oude-Breuil 2015, Nagy 2016), which has a distorted notion about Roma migration (Kóczé 2017), considering it a "security threat" (von Baar 2017), by employing the tactics of ethnic (Roma) invisibility and playing up their Hungarian identity in public spaces, as one of our case studies demonstrates.

\section{Research methodology}

In pursuing the anthropological thread of mobility studies, following mobility trajectories, and studying our moving subjects, we have observed during the past three years two of the most typical and widespread mobility routes of social groupings, especially those of low-skilled mobile Roma laborers from Peteri and its surrounding settlements to their destinations in Canada and the UK.

The empirical findings and the argumentation in this paper benefit from mixedmethods research: we carried out several short-term participant observations and periods of ethnographic fieldwork both in the sending locality (Peteri and its 
surrounding settlements) and in the receiving ones (Toronto and an urban city in the UK). We also conducted 120 semi-structured interviews, focusing on life- and migration trajectories with trans-national migrants who had returned to Peteri, or relocated either to Toronto or in England. Among them, 80 interviewees were (selfidentified) Roma, while 40 were non-Roma. The participants were selected by using the snowball sampling method, and the selection criterion was that the interviewees should have had cross-border migration experience within the last ten years. The length of the interviews varied between 60 and 90 minutes. The interviews were audio-recorded and transcribed.

Along with the qualitative research methods, and with the help of local Roma research assistants, we also managed to implement a survey in the region among the 642 families who had taken part in any kind of trans-national migration since 2012. ${ }^{4}$ We defined the region as the area within a 70-kilometre radius of the city of Miskolc. People from any settlements were subject to questioning, except for those actually from Miskolc. This means that our sample contained only socioeconomically disadvantaged settlements, none of which had more than 33,000 inhabitants. Snowball sampling was applied to select the participants of the research. The selection and the questioning of the respondents was the task of the four local Roma research assistants; that is, the sample is based on their networks, which increased the homogeneity of our sample. The Roma research assistants also helped us achieve another goal of the sample design, namely, the over-representation of Roma migrants. Although the empirical findings of this paper are only valid for the studied social and spatial context, their relevance stems from the explorative nature of the work.

\section{Research setting: different migration trajectories}

Peteri is situated in an economically backward county, Borsod-Abaúj-Zemplén (BAZ), in North Hungary, according to the official statistics on unemployment data. (Since 2010, when a new wave of outmigration has evolved, the unemployment rate was around $20 \%$ compared to the national average of $10 \%$ ). This small rural town is itself not considered among the most disadvantaged settlements as designated by a 2015 government order $^{5}$ regarding an official, complex developmental index (compiled of different socio-demographic-, housing-, labour market-, local economic- and infrastructurerelated indices). However, regarding the other official development measurement, the unemployment index (which defines a settlement as disadvantaged if the unemployment rate of its local population is 1.75 times higher or more than the national average rate), Peteri is indeed a disadvantaged town. Until the end of the 1980s and the beginning of the post-socialist transformation, most local skilled and unskilled individuals (men

4 The advantages and the limits of involving local Roma participants as assistants in the research is discussed elsewhere (Durst 2017, see also Matras and Leggio (2018) for the experiences of the MigRom project).

5 See http://www.magyarkozlony.hu/hivatalos-lapok/c7906e368088af259ea68621e00e02277f38b2ab/dokumentumok/184e1f87 8cb59cd3f0dc13264dca53efedf79d82/letoltes 
and women, Roma and non-Roma), worked in nearby industrial factories. From this state of almost full employment, most of the local population (except the political elite and the the very few people with degrees who had jobs in local government and in schools) have now experienced some period of unemployment. The biggest losers of the transformation in Peteri, as is true of the whole country (Ladányi - Szelényi 2004), are the unskilled or low-skilled Roma with low educational attainment (on average having only completed primary school). Many of them have struggled with chronic, long-term unemployment until recently, when Bosch started to recruit even the unskilled Roma for the least prestigious work on their assembly line. ${ }^{6}$

In Peteri, along with a few other settlements in the region which are characterized by a high rate of out-migration, a "culture of migration" has evolved during the last decade - since around 2009. (See also Hárs 2016 for Hungary). The importance of this culture in promoting cross-border, geographical mobility is documented by scholars (among others, Kandel - Massey 2002). The empirical findings of Massey and his co-author show that, within such communities, transnational migration has become so deeply rooted that the practice of cross-border movement for work has become the norm.

This is exactly the case in Peteri, and especially in its segregated Roma settlements where low-skilled Roma (approximately 3,000 people) live. In the locality of the town, as elsewhere, transnational mobility has differentiated patterns among people of different social (and educational) status and ethnic belonging. At the top of the local social hierarchy are the political and economic elite, who do not migrate as they have reasonably good jobs locally. Neither do skilled Roma workers pursue a cross-border mobility strategy to improve their standard of living; they rather commute weekly (hetelnek) either to the capital, Budapest, or to other big and more developed cities in Hungary. Nowadays they can easily find work in the construction industry, organized mostly by informal labour recruiters, where there is a growing shortage of reliable, skilled workers due to the mass outmigration of Hungarian employees (Blaskó - Gödri 2014, 2016, Hárs 2016, 2018). These Roma men prefer not to leave their families behind, unlike many of their Hungarian counterparts of the same vocation. They are also happy with their social status in their own communities and believe that given they cannot speak a foreign language their status abroad would only deteriorate. As one of them explained to us, "Why would I be a nobody in Canada or in England when I am somebody at home in the town and around?"

On the other hand, among the two most typical groups of local migrants from Peteri - that is, unskilled or low-skilled Roma with eight years of schooling, and nonRoma Hungarian skilled laborers -, one can observe enormous mobility. Among the non-Roma, men with vocational training, mostly in their late twenties or of middle age, have been working for different German companies for three to five years already,

6 Since 2008, Bosch, a multinational company, automotive manufacturer, and a leading developer of future technologies, has relocated its operations from Germany to Miskolc, the region's capital city. The Bosch Group was celebrated as the "Workplace creator of the Year" a few years ago in the Hungarian media (Bosch Media Service 2017). Bosch seems to increase its competitiveness in a stagnating European market through capitalising on lower Hungarian wages. 
mostly in construction, but some in the food industry. They leave their families (wives with younger children) behind in the hope that they can earn enough money within a few years to pay back family debt, renovate their houses and educate their children. That is, they can "get ahead" financially. The basis of their conscious calculus about the cost-benefit of working abroad is that they can earn a salary four times as high as they could do at home. Those few non-Roma who have no vocation and only a primary school education (as is also the case with the vast majority of Roma in Peteri) also typically migrate to Germany or the Netherlands on their own, using their migrant friends' or nuclear family networks. They take up seasonal work as unskilled laborers.

Since the beginning of the 2000s, but mainly in between 2010 and 2013, the most typical migration trajectory among the low-skilled, poor Roma involved going to Canada and applying for asylum as a refugee, or when being deported or coming back to Peteri due to homesickness or to care for an old parent who had fallen ill, to move on to England. ${ }^{7}$ From our interview data as to why they chose their particular destination countries, it was clear that what mostly attracted the Roma to Toronto, apart from the ever growing translocal migration network (constituted by kinship ties), was the country's humanitarian treatment of refugees, who were, among other things, entitled to social provisions that covered at least their housing costs. As many of our respondents articulated, they had fled from racism, hate crime (among others the Roma murders in 2008-2009), and poverty, but as one put it, corresponding with a couple of others, he could not go to other countries, as he "did not have the talent" (tehetségem) 8 to start anew, except in Canada. In Toronto I had relatives with whom we could stay in the first few weeks. Here one can start a brand new life in three months - that's how long it takes to arrange your paperwork - , and Canada welcomes the Roma."

For the Roma in Peteri, as elsewhere for low-income families (Stack 1973), kinship network as a form of social capital is the biggest (and sometimes only) "profitable" resource (Czakó - Sik 2003) that can be used in the process of migration. Wherever migrants move to, even if they have no command of any foreign language, due to their kinship ties they are well informed about the income-earning opportunities, and about strategies on how to cunningly overcome unwelcoming, restricting mobility policies (see Nagy 2016). ${ }^{9}$ Recently, the most common migration trajectory among the Roma from Peteri is their typically recurring but in some cases permanent relocation

7 To discourage Roma from fleeing to Canada, between 2002 and 2008 Canada introduced a visa requirement for Eastern European citizens. In 2008 this was lifted, but again in 2013 there was a substantial reform of the Canadian system for determining refugees. The reform took place in addition to some political action aimed specifically at the Eastern European Roma who in the political discourse were accused of being "bogus" or "economic refugees" (Levine - Rasky 2016).

8 Our informants" use of the word "talent"should be understood as capability.

9 Those who cannot even rely on the assistance of their kinship networks as a resource for reducing the cost and risk of migration are the most vulnerable among the poor migrants. These are men who have gone through eight years of schooling who became mobile workers after commuting to Germany or the Netherlands on a six-weeks'-work, one-week's-holiday basis, or most recently to Spain to perform, as they say, "even bottom-end labour." Established, organized networks have recently been developed between formal employers in some Western European countries and informal recruiters (who have previously been employed by the former employers) to encourage unskilled people, mostly in an economically vulnerable situation, to temporarily work in these countries by facilitating their travel (using money informally lent by the recruiters, with added interest), accommodation and employment. We carried out interviews with nine of these informal labour intermediaries from neighbouring settlements - from all their clients there were none from Peteri. This clearly shows that potential migrants prefer to use kinship networks to facilitate their work-related cross border movement if they have a choice. 
and work-related mobility to some urban UK cities with abundant job opportunities, facilitated partly by kinship networks but mostly by ubiquitous labour market intermediaries. In the following, after presenting our survey results, we explore two of the most typical migration patterns for Roma and non-Roma respectively, with a focus on their interaction with development.

\section{Results of quantitative research}

In this section we describe whether there are statistically significant differences in the migration patterns of our Roma and non-Roma respondents by using the results of our questionnaire.

A total of 642 respondents answered the questionnaire, $70 \%$ of whom were (selfidentified) Roma, while 30\% were non-Roma. Men were over-represented both in the non-Roma and Roma sub-sample (see Table 1 in Appendix). Most of the non-Roma (69\%) respondents had completed at least vocational training school, while $31 \%$ of them had at most a primary school education. In the Roma sub-sample one-third of respondents had (at least) vocational qualifications, and two-thirds of them had a maximum of primary school education (see Table 2, Appendix). Nearly two-thirds of the non-Roma and almost half of the Roma respondents had a permanent job: temporary jobs and unemployment were more frequent among the Roma (see Table 3, Appendix). Seventy-three percent of the Roma and 63\% of the non-Roma interviewees had a spouse or partner. The average household size was 4.6 individuals in the total sample, being 3.9 persons in the non-Roma and 4.9 persons in the Roma sub-sample.

We examined whether there was a significant difference between the Roma and non-Roma respondents in terms of which destination country they prefer to move to. According to our results, Canada and the United Kingdom are more popular destination countries among Roma, while non-Roma are more likely to move to Germany and to "Other" countries ${ }^{10}$ (see Figure 1). Cross-tabulation analysis was used to study the relationship between the chosen destination country and ethnicity (in another study we carried out a regression analysis that proved that ethnicity is associated with the chosen destination country, even when controlling for level of education (Durst - Nyírő forthcoming 2019).

10 We merged all destination countries into the category of "Other countries" except for the United Kingdom, Germany and Canada because of the low number of cases. 
Figure 1: Chosen destination country by ethnicity, $N=640$

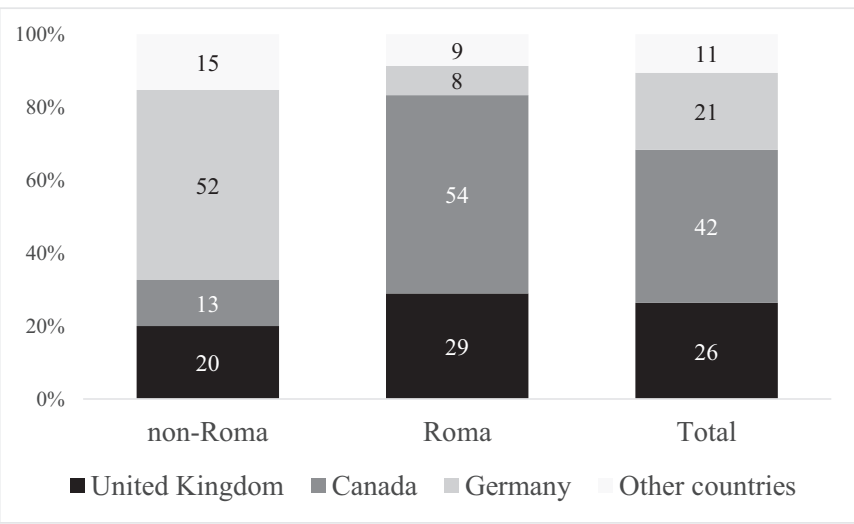

The survey results confirmed the experience of the ethnographic fieldwork that there is a difference between Roma and non-Roma in terms of the role of kinship networks in the realization of migration. We found that both Roma and non-Roma respondents relied heavily on their social networks in their migration, although non-Roma mostly received help from their acquaintances and friends, while Roma used their family networks. For instance, most of the Roma respondents moved to settlements where they already had family members, while the non-Roma selected settlements where their friends had been living (see Figure 2). Furthermore, most of the Roma interviewees received accommodation from a family member at the beginning of their time abroad, while the majority of non-Roma interviewees stayed at a place provided by their workplace (see Table 4, Appendix). Finally, we found that Roma respondents typically relied on their family for job-seeking, while non-Roma respondents mobilized their friends in order to find their jobs (see Figure 3).

Figure 2: Distribution of respondents according to whether family members or friends lived in the settlement the respondent arrived at before the respondent moved abroad, $N=636$

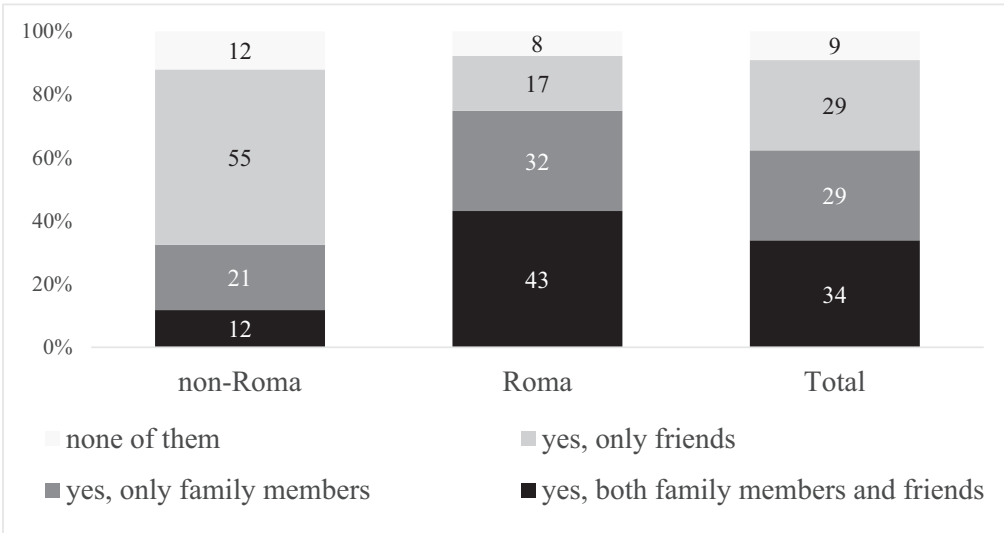


Figure 3: Distribution of respondents according to who helped them to find a job when they first moved abroad, by ethnicity, $N=580$

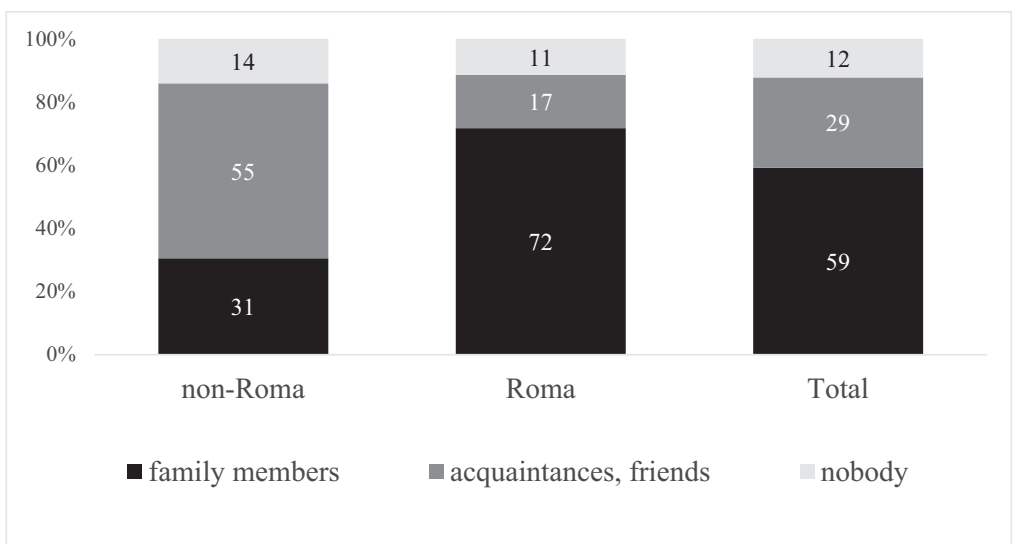

Another difference between the migration patterns of Roma and non-Roma respondents is that most of the Roma migrants moved abroad with their families, while the majority of non-Roma migrants migrated alone.

Figure 4: Moving abroad with or without family, by ethnicity (\%)

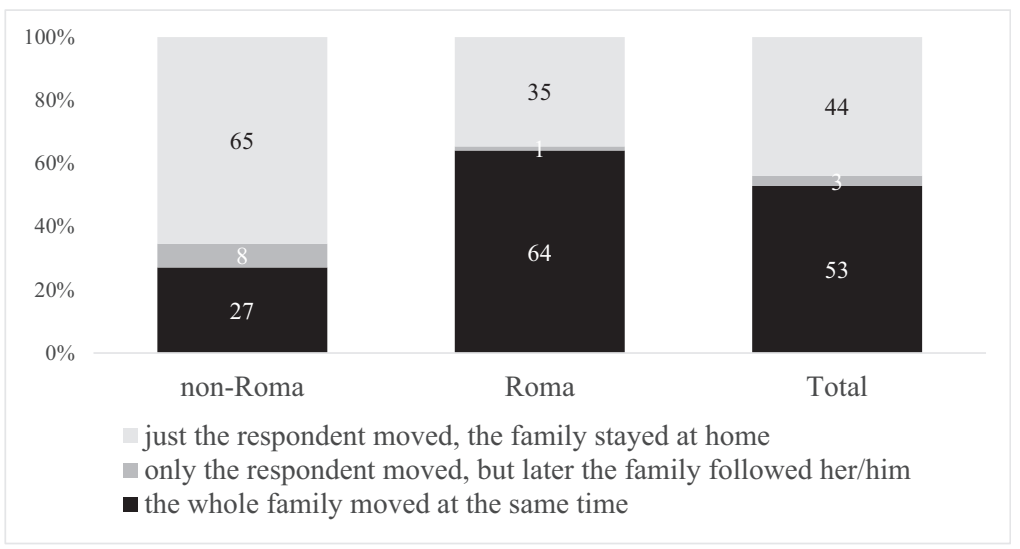

Regarding the practice of sending remittances, we found that almost the same proportion of non-Roma (69\%) and Roma (70\%) respondents sent remittances to their home country. However, there were differences between the two sub-samples according to the aim of the remittances, with a significantly higher proportion of non-Roma (40\%) sending money to their family members than Roma (31\%). Debt repayment was more frequent among Roma respondents (18\%) than among nonRoma (9\%). Finally, Roma migrants were more likely to send remittances to further their own goals (e.g. home purchase, renovation) compared to non-Roma (44\% vs. $35 \%$, respectively) (see Table 5-7, Appendix). 
In summary, we found several differences between the migration patterns of Roma and non-Roma migrants. First, regarding different destinations countries; second, Roma respondents mostly relied on their kinship networks in the realization of the migration, while non-Roma migrants received assistance from their acquaintances and friends; and third, their practice of sending remittances were also distinct.

However, as we mentioned earlier, the presented results only describe the first steps of our quantitative research, thus further analysis of the database is needed.

\section{Ethnographic findings}

Roma migrants from Peteri with whom we had regular contact through our fieldwork are concentrated in low-wage, low-skilled, labor intensive jobs in a few English urban cities, along with other mobile CEE migrant laborers working in the UK (Ciupijus 2011). For these individuals, "whose bodies are historically marked by their racialized darkness" in their home societies (Grill 2017), moving to the UK provided an escape from ethnic labeling and stigma - although simultaneously exposing them to different categorizations; that is, the inferior label of "Eastern-European migrants" (Grill, 2017) (meaning in many cases, an unskilled, flexible and exploitable work force).

Most of them, even those who had been working in England intermittently during the past few years, offered their labour as agency workers at significantly lower wages than contracted (mainly "native" English) workers on multinational factories' assembly lines in urban cities in the UK (Durst 2018). Part of the social transformation of the "glocalised" (Robertson - White 2007) labour markets in England is that practices of flexibility dominate corporate strategy across many sectors of the economy. At the forefront of these changes is the fast-growing institution of labour-market intermediaries (Enright 2013) that are used by migrant workers to enhance their chances of finding work on an unknown, volatile foreign labour market. For most of our interlocutors, these recruiting, temporary staffing agencies facilitated their mostly temporary but, in some cases, permanent employment - despite the language barrier.

Laló, a 28-year-old man from the segregated neighbourhood of Peteri, can be regarded as a typical low-skilled Roma migrant agency worker with a transnationally mobile life. He finished eight years of schooling and is a father of two young children, aged eight and ten. Laló was twelve when he left the Roma settlement for the first time in his life, for Canada. He had been there with his parents and siblings for two years when his mother decided to come home to look after her terminally ill father. "I think they just missed giving our family a chance," Laló told me when we spoke about his Canadian experience that he still cherishes. When they came home, Laló had to go back into year six of primary school where he had been studying when they left. Local schools in Peteri do not acknowledge school certificates from abroad. Laló, being a big 14-year-old boy, hated going to school and being put back into a class with kids two years younger than him, so his mother arranged for him to be a private pupil. At the age of 18, Laló finished the compulsory eight 
years of primary school, thanks to a governmental initiative supporting adult education. He went on to do seasonal jobs locally, got married and had children.

In 2010, when many of his Roma kin and friends from the settlement started to move to Canada again, this time in massive numbers, he decided to join them. In the transnational space (Glick Schiller 2009) created by the constant communication through social media (Facebook, Messenger and Skype chats) between migrants and family members left behind, his aspirations for a better life emerged, to be achieved either in Canada or in England, where many Roma from Peteri had carried on their sojourns after coming home or being deported from Toronto. This second time he spent two years in Toronto and saved enough money from combining "off-the-books" (Venkatesh 2006) casual work with welfare - as many people of a marginal position do all over the world (MacDonald 1994) - to renovate his dilapidated house before he came home. "The heart pulls most of us back home," he recalled, explaining why they returned to Peteri.

After a few months, when the family had spent all their savings from Canada, they went on to Nottingham in England. When we asked him why Nottingham, he replied, as if it went without saying, that: "It's obvious: one goes to cities where one has kin, where the rent (for private apartments) is affordable, and most importantly, where there are jobs." He was first recruited by the agency that his cousin introduced him to and the agency sent him to a pizza factory. But after three months the factory gave up all agency workers, keeping only its own contracted workers as there was low demand on the market for its product. Then he went to Nelson where his other cousin lived, who introduced him to his local agency. There, in a "biscuit factory," he worked as a packer on the assembly line, along with many other Hungarian co-workers. He only managed to work for four days a week, whenever the agency called him, but after a few months, the "work stalled again." Even if Laló moans about the situation that "in England there is only seasonal work," he still considers working there much better than in Hungary.

We met Laló a few weeks ago when he went home to Peteri for a while since his work in the biscuit factory had come to a halt. Laló tried to find a job nearby, so as to be close to his family. He went to Bosch, which had recently become the biggest employer in the whole region, to work on the assembly line. But he could not endure more than four days there. "England is hundreds of times better," he reasoned to me about why he left Bosch.

In England there is equality. Over there, when my Polish co-workers once tried to call us "stinking Gypsies" (büdös cigány) and started to bully us, I reported them to my boss, and they got a warning. The next day they apologized. Here in Miskolc [where the factory is situated], a Gypsy is never right. Also, in England, they treat their workers better. Here at Bosch, in your twelve-hour shift, you have two fiveminute smoke breaks plus one half-an-hour lunch break. There are women who faint on the assembly line. The ambulance is there daily. And for enduring all that 
work, you get a salary of 120,000 forints (appr. 400 euros). You earn four times more for less work under better conditions in England.

Laló, like many of his Roma fellows, says that if there were opportunities locally to obtain a decent job with a reasonable salary that one could support a family with, people would not go abroad to work.

Why would I go?! Everybody likes to stay around his family, help his parents in their old age. But we have no other choice but to work abroad. It's not only that you can earn four times more in England. But it is also how they treat you. Okay, there is racism everywhere in the world. But in England it is not so bad as it is in Hungary. In England, you are equal, they do not care whether you are darker: you are not a Gypsy here but a Hungarian, a human being. They are only interested in whether you can work hard or not.

Living and working in England for many years, Laló, like many other Roma return migrants, can no longer imagine himself in the "modern sweatshop" (modern robot világa) as he calls Bosch. He intends to carry on with his trans-regionally mobile workers' life, meaning labouring in England for five to six months a year while he is "compelled to do that" (rákényszerül).

Unlike Laló, some older Roma non-migrants still consider Bosch their only opportunity to find employment. They argue that this is the only local company that offers a chance to make a livelihood even to unskilled people and especially to Roma, who are not likely to find any employment elsewhere in the region because of their low level of schooling and dark skin. In contrast, many return migrants, including Laló, underwent a perceptual shift as a result of working abroad. They have greater expectations now about how a human being needs to be treated, whether Roma or non-Roma.

This self-developmental trait can be traced in the narrative of a few local members of Laló's kinship network from Peteri. Karol, a middle-aged woman of four children, believes that the Roma have "developed since they started to migrate," for the first time in their lives, as they have experienced "what it means to be treated equally, as a human being, and not as an inferior Gypsy." She went to Toronto in 2011 with her husband and kids following her sister's family, who helped them during the first few weeks by accommodating them and by introducing her husband to work in the same carrot factory at which her brother-in-law was a day-laborer.

Karol recounts her family's positive experience during their two-year stay in Toronto.

I think that by going to Canada we put something in the hands of our children. First, they learnt English in the school over there. But, even more importantly, by showing them that there is a bigger, different, and better world outside our contained Gypsy settlement, their eyes have opened. They can now compare the life here in Peteri and over there in Canada. They now dare to aspire to have 
a vocation with which they will try to find a job abroad. Maybe in England or Germany.

Nowadays, in the Roma settlement of Peteri, many youngsters, among them Karol's two older children, students at nearby vocational secondary schools, agree with Laló that workplaces such as Bosch do not offer a reasonable opportunity for people who would like to get ahead in life. These teenagers, themselves having spent $1.5-2$ years in Toronto on average, are pushed by their parents to obtain vocational skills so they will have a future. They have started to develop bigger aspirations, thanks not only to their own experience abroad but also that of their relatives with whom they are in everyday contact through social media. Karol's daughter plans to be a chef, and her 18-year-old brother a welder. After finishing their vocational training in the nearby town's secondary school and working for one or two years in Hungary to get work experience, they both plan to move to live and work abroad - the boy in Germany and the girl in England. When we asked the girl why she had chosen England, she showed us some pictures of her uncle's house in Liverpool, saying that they had managed to create a much nicer life and even support their daughter's further education by working hard. A life that one cannot even dream of in Peteri.

A similar, frequently told story in the settlement among the local Roma is the success in higher education of the daughter of Laló's relative, Robi. The story of this case has travelled throughout the whole settlement as a good example of "what a Gypsy kid can achieve" if they are in an accepting social environment. Most of Lalós kinship network seem to know, even those who have never actually met Robi's family, how successful their migration has been.

I have now known Robi and his family for years. During my fieldwork in the English city to which they relocated their family to work in a factory to build a livelihood and create a better future for their children, it was obvious to me that they use the strategy of ethnic invisibility cleverly in public spaces in England (see for similar experiences Nagy 2017). Being aware of the distorted media images about CEE Roma migration (Kóczé 2017) - called "Romaphobia" by many scholars (Tremlett et al. 2017) - Robi and his family play up their Hungarian identity in England in certain situations when they need to get better treatment. The following story is a case in point.

One day we accompanied them to the gym in their English city's immigrant neighbourhood, which is populated, among others, by many Romanian Roma migrants. They asked us to help them enrol in the gym. The receptionist found their darker skin complexion similar to that of the Romanian Roma, some of whom are members of the gym, and inquired as to whether they were Roma too. "No, no, no Roma, Hungarian," explained Robi and his wife, almost immediately to the receptionist, articulating loudly their nationalities. Being a Hungarian is of much higher value in England than 
being Roma (which word is often confused in English people's minds with the word Romanian; see Guy 2003, Durst 2016). ${ }^{11}$

Robi's daughter educational success, the exact details of which people back in Peteri do not know about, was due partly to Robi's strategic planning as to which school he sent his children to. After learning from their other migrant Roma friends' and neighbours' bad experiences about how "Hungarian Gypsy kids are badly treated by their English teachers in the local school (which is full of the children of migrants) when they are in group," Robi and his wife did not let their kids attend the local school but found another one, although much further from their residence, that welcomed their children as the first Hungarian kids in their institution. The teenage children learnt English fluently and left that secondary school with good experiences. Robi's daughter, Marika, a 17-year-old girl, is continuing her studies at a BTEC secondary school on a business course, which may lead to further education. "This is the first time we had a Hungarian girl in this school," said her form teacher with a kind smile when we accompanied Marika with her mum to a recent parent's evening. "Marika has established a very good reputation for Hungarian pupils. She is industrious, proactive in her studies, and she herself did all the research necessary for her university application next year."

In Peteri, however, non-Roma migrants only got the "rumours public" (Harney 2006, Humphris 2017, Durst 2018) about how successful Robi's daughter is. These stories, mostly heard of through Facebook, or in rare cases due to first-hand experiences on the occasion of personal visits, have been circulating persistently among the Roma in the settlement. They inspire and develop the imaginations of the younger generation of local Roma (migrants and non-migrants alike), encouraging them to form aspirations that they have not before imagined: the thought that such success could be a real possibility for Roma with a poorly educated family background.

Using Sen's (1999) concept of development, we can interpret Laló's and his Roma network's recurring migration (facilitated by the support of their kinship and the labour demand of their destination regions) as an enhanced capability of mobility, and an increasing practice of agency. Their very act of geographical movement, especially trans-nationally, or rather trans-regionally (recently, between Peteri and one or two English cities where they have relatives), against all structural constraints, restrictive mobility regimes (Glick Schiller - Salazar 2013) and despite their lack of financial resources and command of English, can be considered a form of development.

Agency here is understood as both the intention and the practise of acting in one's own self-interest and the interest of one's family or household (Castree et al. 2004, cited by Rogaly 2009, Emirbayer - Mische 1998). In the case of our low-skilled Roma

11 It should be noted though, that not all Hungarian Roma can resort to the tactics of ethnic invisibility. In this very same English city a more traditional Vlach Roma group from South Hungary reside in the close vicinity of a Romanian Roma kin network. The latter are infamous in the neighbourhood for their informal income-generating practices. Because of this particular, denigrated residential address, some highly educated members of this southern Hungarian Roma group complained to us that even in England they couldn't escape the stigma of being Roma. 
migrant research participants who live in Peteri, a local society "in which the future has become synonymous with geographical mobility" (Narotzky - Besnier 2014:2), one's agency is deeply connected to one's spatial mobility.

As this case study shows, we can regard labour migration as "an act of hope" (Pine 2014) for people struggling with poverty, such as those in our studied Roma kinship networks. The latter believe that with the blocked field of opportunities in their homeland, the only way to achieve a better life both for their households but especially for their children is to pursue a strategy of cross-border mobile work. We argue that their very act of moving not only involves resilience (Acuna 2016, Levine -Rasky 2016) but is also a small development in itself: an enhancement of their own and perhaps also their network's capacity of aspiring to escape poverty and get ahead in life.

We believe that the thesis that (increasing) mobility in itself can be considered development (see also de Haas 2008) is valid in our case, even if we are aware of the fact that Central Eastern European Roma's mobility is “contained” (van Baar 2017), both in terms of the Canadian asylum-seeking (Ciaschi 2018) and in the European free labour movement context (van Baar 2017, Yildiz - De Genova 2017, Nagy 2018), due to selective mobility regimes. Our Roma research participants' geographical movement as an act of hope is a result of their choice of a mobility strategy - even if this choice is "constrained". Widmer et al. (2010: 114) draw attention to the fact that all seemingly free decisions result from adapted choices within a system of constraints. This is particularly true in the case of our low-skilled Roma migrants whose decisions to migrate are adapted choices to the shrinking opportunity field in their home country.

For non-Roma Hungarians from Peteri, trans-regional mobility, or working abroad (as guest workers), is also a constrained choice, similar to that of many other precarious Hungarian migrants (Németh - Váradi 2018, this issue; Melegh et al. 2018, this issue). However, their migration trajectory is different, and so are the characteristics of their migration network and the outcomes of their geographical movement.

Zoltan's trans-regional work-mobility trajectory can be considered typical in Peteri among the skilled, non-Roma Hungarian men. Zoltan is a 41-year-old carpenter and has completed vocational secondary school. He has been working in Germany for the past three years as a skilled labourer at a local firm in the construction industry. He found his job with the help of an old friend who had worked for the same company. He has been married for 25 years to a saleswoman from Peteri, and they have one daughter, aged 19 .

Recalling the reasons he was "compelled" (rákényszerült) to find a job abroad to us in an interview, he said that he did it for his daughter.

I and my wife concluded three years ago that we must do something to be able to support our daughter's secondary education. That was when I called up my friend to help me to find a job in Germany. We decided that my wife should 
stay at home to look after our daughter while she is studying; it is the only way that working abroad is worth it financially... Here in Hungary you cannot earn enough to keep a family. And my daughter's high school was demanding... It was a medical vocational school, where teachers and your classmates expect you to dress properly; there were school trips, extra curriculum expenses, and the monthly travel cost from Peteri to Miskolc [where the school is based]. If one added it all up, the 130,000-forint salary that I could earn in Hungary was enough for nothing. Since I am the man of the house, I had to sacrifice myself for our daughter's future.

Zoltan has been working for the same German firm for the last three years, six days a week, for 8 - 10 hours a day. He earns 1500 euros (450,000 forints) per month almost three times more than he used to earn at home, but less than his "native" German workmates earn for the same labour. Out of this sum, he monthly remits 1000 euros (300,000 forints) to his family. His daily menial work is tedious and hard to endure, his housing is nothing compared to his family house in Peteri. He shares a room with two other Hungarian workmates who are there for similar reasons as Zoltan. On their only spare day, Sunday, they do not want to do anything but cook, eat and have a rest. Zoltan can only get a one-week holiday once every four months, when he goes home to Peteri to see his family. "I do not carry on with this working abroad, away from my family, from any sense of pleasure (jókedvemból)," he said to us last time we met, a few days after Christmas when he was back home for a couple of weeks due to the winter closure of his company.

I do it for my family to get ahead. Since I've been working abroad we have managed to renovate our house and bought a new car. But I do it mainly for my daughter's future, for her to have a better life than we have. Although she misses me, she knows that it is out of necessity, a constraint (kényszer). Yes, it is a constrained choice (kényszerú választás) of my wife and me. I must take this job in Germany which pays three times more than I can earn in Hungary if we do not want our daughter to have such a hard life as we have had. What can one do if he has no other choice but to work abroad where his labour is decently paid? I cannot imagine myself coming back to Hungary and working again for ten hours per day for 130,000 forints. And I am pessimistic about this situation changing in the near future. I am not alone in this opinion. So many people leave Peteri to go abroad, be they Roma or non-Roma, to create a better livelihood for their families.

The downside of Zoltan's working abroad, in his account, is that he feels that he and his wife have become alienated for the last three years.

It is not the same between us as it used to be before I left. Even my daughter feels this. It was, however, our mutual choice, so I am hopeful that my marriage will survive this period, me being away. One has nothing more important than their child and her future... I'm happy to see that my daughter is making progress with her studies; she is now in higher education, training as a medical masseuse. She 
sees her future as working abroad later, as she says, because with her qualification she can earn six times more than in Hungary. I understand her intentions. Since she has studied that much and since I have invested so much money in her studies, and I have sacrificed myself and my marriage for this, I would like to see that it is worth it. That she can get ahead in life.

Zoltan's labour migration strategy can be considered typical among the many Hungarian skilled laborers in Peteri. For them, labour migration is a constrained choice - a deliberate and conscious strategy, that is, however, strongly limited by structural constraints. Namely, by the lack of jobs with a decent salary in the proximity of the home town, enough for one to support a family according to family members' aspirations. Zoltan's and his other guest-worker mates' remittance-sending strategy aims to contribute to the financial betterment of their nuclear families and to facilitate their children's further education. In their narratives about their migration history, the word "sacrifice" comes up often. This is a household livelihood strategy which has a very narrow developmental effect, and mainly in a financial sense. It cannot also be considered a transnational life in the sense that recent migration studies argue. Namely, that in the new globalized world there is a "transnational turn" and the lives of migrants are increasingly characterized by circulation and simultaneous commitment to two societies and to adopting transnational identities (Glick Schiller et al. 1991, Guarnizo et al. 2003, Vertovec 1999, De Haas 2005). For Zoltan, as for many of his local friends in similar social circumstances, Germany represents a place where they do not want to integrate but rather to work to earn enough money to make a better life for their families they have left behind. However, this householdlevel financial advancement ("development" in the narrow sense, as international financial institutions understand it) does not seem to lead to development in the migration-sending community level. Not only due to its huge social price in respect of the decline of his marital relationships. Zoltan, along with his other co-guest workers, also do not plan to invest in any local businesses or enterprises at home except in his children's education (however, his daughter also plans to work abroad after getting qualifications in Hungary).

Zoltan's case, along with that of many other Hungarian skilled labourer migrants from Peteri, supports another observation. Namely, that the nature of the migrationdevelopment nexus is fundamentally contingent on more general developmental conditions in the sending region (De Haas 2008). In other words, development in migrant-sending localities is a prerequisite for return and investment (De Haas 2008). As Zoltan put it: "There is no point in investing in a life at home in Peteri. I cannot imagine myself coming back and working for that small amount of money again. I do not see any sense in returning. Only if the situation and the economy improves. But I am rather pessimistic in this regard. I think we are the victims of the system in Hungary." 


\section{Migrants as "agents of development"? Remittance-sending behaviour in Peteri}

As we have shown earlier, according to our survey results most migrants from Peteri send remittances to their hometown. However, there are differences among Roma and non-Roma remitters' practices regarding how this money is spent. On the basis of our interview data we can add there are also differences in the amount of regular or less regular monthly remittances.

From our ethnographic fieldwork it is clear that migrants' remittance-sending patterns are linked to their migration patterns. First, to the conditions they experience in their destination locality (see also Glick Schiller 2009). Second, to the characteristics of their migration (for example, whether they moved with their nuclear or extended family, or they left behind other family members).

In Peteri, according to our interview data, non-Roma Hungarian skilled migrant workers, similarly to Zoltan, send remittances home of significantly higher amounts than Roma low-skilled mobile workers. While the members of the former group regularly send most of their monthly salaries back to Peteri to their wives (on average, as the wives we interviewed reported, around three hundred thousand forints), the low-skilled Roma, the majority of whom move together with their whole families, send only small amounts home. The conditions they experience in their destination countries do not make it possible for them to remit regularly. In Canada, many of them spent huge amounts of money on lawyers to help them navigate the very complicated asylum-claiming legal process. In England, unlike in Germany, employers do not provide them with accommodation, therefore they need to spend a good portion of their salary on renting a flat. Although many of them are entitled to housing benefit due to their low income, this form of government aid has constantly been cut back for migrants in recent years (see also Greenfields - Dagilyte 2018). Therefore, it is no wonder that, unlike the non-Roma, low-skilled Roma migrants do not remit on a regular basis but mostly only to help in crisis situations concerning their non-migrant extended families (for medicine or hospital treatment, to buy wood for heating a house during a cold winter, towards the cost of surgery of an ill child within the kinship, etc.). However, those Roma in Canada who plan to come back in the near future to the settlement send regular smaller amounts (less than one hundred thousand forints every few months) to a trusted close family member's account (mainly their parents') for the purpose of renovating their own houses on their return.

For non-Roma skilled laborers, their remittance-sending practices have developmental effects, but mainly in financial terms, associated with materially getting ahead. Their families use the remittances to refurbish their houses, educate their children, repay debt and increase their consumption (see also Váradi 2016). However, this material advancement comes in some cases at a huge price. Fathers who are away for three to five years, and who visit home only for one week every eight weeks, can only take part in the lives of their children and wives through regular Skype conversations. Divorces occur due 
to these long-distance relationships. As one of the local Hungarians said to us when we asked whether he was planning to work abroad, he would never do that without his family, as "it is like the life of the lorry drivers. Out of ten, six are divorced."

For low-skilled returning Roma migrants, not only is their migration pattern different but also its financial outcome. In a financial sense their transnational mobility is not as profitable and rewarding as it is in the case of non-Roma Hungarians. Many of them say that they feel that they "are stuck," or "spinning around in one place" ( with their "constant wandering" (kóborlás), referring to their recurring work abroad. The majority of them, however, mention that they would never have dreamt of owning a house if they had not gone to Canada (or England). They all stated that from low-paid, menial wage labour one cannot send home remittances to other extended family members, or only in situations of crisis. However, one should also see that their trans-regionally mobility strategy helps them and their close relatives to get by in the shrinking opportunity field in Hungary.

\section{Conclusion: Exploring the migration-development nexus in Peteri}

Based on our empirical findings, we argue for the differential developmental effect of migration regarding Roma and non-Roma migrants or trans-regionally mobile workers in the context of the small rural town of Peteri. Our survey results support the hypothesis that local differentiation (in our case, based on ethnicity) between different social groups has a significant effect on the pattern and organization of their diverging migration trajectories. We found several differences between the migration patterns of the Roma and non-Roma migrants in our studied locality. First, the two groups choose different destination countries. Second, Roma respondents from Peteri mostly rely on their kinship networks in the realization of their migration, while nonRoma migrants receive assistance from their acquaintances and friends. Third, their practices of sending remittances are also distinct.

In addition, our ethnographic findings, through exploring both the causes and consequences of the local population's migration, have delineated the mechanisms through which different migration patterns produce different impacts at the individual, household and local community level.

While our findings support the differential migration-development interaction thesis, they reject purely pessimistic developmental ideas common among researchers who study Roma return migrants in residentially segregated sending communities in post-socialist Eastern and Central Europe (for Romania see Szabó 2018, Anghel 2016, Horváth - Kiss 2015). Our North Hungarian case study draws attention to the fact that the impact of migration in the case of poor Roma migrants and their non-migrant networks is more complex than suggesting it only served to reproduce their poverty and inequality. Along with some prominent labour geographers' attempts (Rogaly 2009) to focus on the low-key and often invisible ways by which people with very 
limited material means practise agency and rework their positions to make a more viable life (Butler 2004) - one, that is in their view, worth living -, we have shown that even those migrants who returned to the segregated Roma settlement in Peteri, with just enough savings to renovate their dilapidated houses, and whose migration stories appear unsuccessful in the eyes of their local mayor, have experienced a kind of development. Their enhanced practice of agency - the very act of the geographical movement -, especially trans-nationally, or rather trans-regionally, against all structural constraints, and restrictive mobility regimes, coupled with a lack of financial resources and command of English, can be considered a form of development.

However, we must add that, up till now, only on an individual level can we see social development, and only in the case of a small fragment of the local Roma community. This development can best be tracked on a cognitive level as a perceptual shift, as the cases of Lalós and Karol's teenage children with their growing "aspirations window" have demonstrated.

On the contrary, for a larger segment of the Roma community, going on to generate income or work in Canada and in England, this was just another workplace where they did not even learn the language, and their children were too small to benefit from a more inclusive and equal education system. These Roma migrants' social interaction was confined to the circle of Hungarian, and, in particular, Roma migrants and they did not benefit from their migration in more than a narrow financial sense - if at all. (This same statement applies to those non-Roma Hungarian men who have been working in Germany during the last few years).

On the downside, concomitant to the cross-border or trans-regional mobility of Roma families, is that much of their children's primary education was interrupted. These children, faced with the lack of a national re-integration program, have dropped out of school, finishing only eight years of study at an older age, if at all. However, we might say cautiously on the basis of our interviews that the Roma children who migrated together with their families seem to have paid less of a price for the move as regards their psychological well-being than those who were left behind by their migrant parents.

From our empirical findings, explored in this paper, a couple of statements from the current academic literature about the nexus between migration and development can be supported. First, that the nexus should be analyzed at different analytical levels as it is muti-layered, and multi-directional, and that the transfer of resources should be explored as a two-way flow (Delgado Wise - Covarrubias 2009, Faist 2009). Exploring the consequences of Peteri outmigration from a global perspective which addresses the movement of people and profits across national borders (Glick Schiller 2009), it is clear that the Peteri migrants, be they low-skilled Roma or skilled nonRoma laborers, are not only remitters but also contribute to the development of the receiving countries "through their capital accumulations... by their transference of their 'surplus population'... as an overall cheapening of the workforce” (Delgado Wise 
- Covarrubias 2009: 85). Our case studies have shown that one of the roles that Peteri plays in the global economy in recent years is providing cheap and flexible, mobile laborers for global assembly lines.

Second, the stories recited above can also be read as a case in point that underdevelopment is a catalyst for migration to developed countries (Delgado Wise Covarrubias 2009). However, we would not call it "forced migration," as Delgado Wise - Covarrubias denominate it, nor would we label it "involuntary mobility," as some anthropologists do (among others, Nagy - Oude-Breuil 2015). Rather, we would view it as a result of "constrained choice."

On the regional and national level, the mass outmigration of locals from Peteri (along with many Hungarians) has indirectly contributed to the increase in labour demand and therefore of income for those who have stayed in their hometown. As the local Roma recall, there was no precedent to what is happening now: "Bosch sends free buses to almost every nearby settlement for its commuters, even if there are only two workers in one village, as there is such a shortage of laborers." Many nonmigrant Roma who used to previously complain about not being able to find any jobs on the formal local labour market because of their low level of schooling and dark skin (a hint as to the labor market discrimination against Roma in Hungary, see Kertesi 2005) are now employed by Bosch, or currently work as unskilled day laborers in the construction industry.

On the local level, in the settlement of Peteri, out-migration, or rather transregional work mobility, similarly to informal income-generating practices, has a "buffer function" (Portes 2010) in terms of alleviating poverty, mainly through migrants' remittances. This is true for both Roma and non-Roma, skilled and unskilled, returned and current mobile workers' households.

All in all, we conclude that in the context of the economically disadvantaged rural town of Peteri, migration has a different developmental effect on the groups of its most numerous migrants, the precarious Roma and non-Roma households. Non-Roma Hungarian skilled labourer, the so called new European guest-workers, through their regular monthly remittances, justify their stays abroad as helping their families to get ahead, but mostly in a material sense. In contrast, in the community of the low-skilled Roma we see some real developmental impact in the sense of increased capabilities (Sen 1999) and, on the cognitive level, in the sense of empowerment (Appadurai 2004). Return Roma migrants seem to achieve much less migration-induced financial advancement than their non-Roma skilled local counterpart. Unlike in other countries (for Romania see Tesar 2016, Toma et al. 2017), in Peteri, no conspicuous houses have been built to show their return migrant dweller's migration-induced increased status. Returned Roma trans-nationally mobile workers have not (yet) managed to move out of their segregated neighbourhood, either, unlike successful migrants in other CEE countries. 
However, we consider the low-skilled Roma's very act of moving (out of their confined, geographically and socially segregated settlement on the outskirts of Peteri) not only as a form of resilience (Clave-Mercier - Olivera 2018, Durst - Nagy 2018) but as a kind of development - in the sense that the former are increasingly putting into practise their freedom (albeit constrained) to choose where to live and work, and that they have taken a step towards enhancing their own and also their network's capacity to aspire. Having said that, migration has not only empowered Roma individuals to dare to aspire higher. There is also the hope that the enhanced aspirations of return migrant teenagers, through their networks which comprise their migrant and nonmigrant kin and friends, and which are reinforced by their everyday contact through social media, might contribute to the strengthening of their community's capacity to aspire (Appadurai 2004). If this happens, there is a chance that these young adults will indeed be able to "get ahead," and to escape poverty should socio-political and economic circumstances change in Hungary.

\section{Appendix}

Table 1: Distribution of respondents by gender and ethnicity (\%)

\begin{tabular}{c|c|c|c} 
& non-Roma & Roma & Total \\
\hline & $\mathrm{N}=190$ & $\mathrm{~N}=452$ & $\mathrm{~N}=642$ \\
\hline women & 28,9 & 38,5 & 35,7 \\
\hline men & 71,1 & 61,5 & 64,3 \\
\hline Total & 100,0 & 100,0 & 100,0
\end{tabular}

Table 2: Distribution of respondents by education and ethnicity (\%)

\begin{tabular}{|c|c|c|c|c|}
\hline & & $\begin{array}{l}\text { non- } \\
\text { Roma }\end{array}$ & Roma & Total \\
\hline & & $\mathrm{N}=189$ & $\mathrm{~N}=452$ & $\mathrm{~N}=641$ \\
\hline \multirow{2}{*}{$\begin{array}{l}\text { no more than primary school } \\
\text { education }\end{array}$} & less than primary school education & 4,8 & 9,1 & 7,8 \\
\hline & primary school education & 25,9 & 57,7 & 48,4 \\
\hline \multirow{2}{*}{ at least vocational education } & vocational qualification & 51,3 & 28,1 & 34,9 \\
\hline & at least high school education & 18,0 & 5,1 & 8,9 \\
\hline \multicolumn{2}{|c|}{ Total } & 100,0 & 100,0 & 100,0 \\
\hline
\end{tabular}


Table 3: Distribution of respondents according to whether they have a job and by ethnicity (\%)

\begin{tabular}{c|c|c|c} 
& non-Roma & Roma & Total \\
\hline & $\mathrm{N}=177$ & $\mathrm{~N}=418$ & $\mathrm{~N}=595$ \\
\hline permanent job & 66,1 & 49,3 & 54,3 \\
\hline temporary job & 14,1 & 19,9 & 18,2 \\
\hline no job & 19,8 & 30,9 & 27,6 \\
\hline Total & 100,0 & 100,0 & 100,0
\end{tabular}

Table 4: Distribution of respondents according to who provided them with accommodation when they first moved abroad, by ethnicity (\%)

\begin{tabular}{c|c|c|c} 
& non-Roma & Roma & Total \\
\hline & $\mathrm{N}=180$ & $\mathrm{~N}=437$ & $\mathrm{~N}=617$ \\
\hline family members & 25,6 & 66,6 & 54,6 \\
\hline acquaintances, friends & 6,1 & 9,2 & 8,3 \\
\hline workplace & 46,1 & 11,2 & 21,4 \\
\hline rented apartment & 20,6 & 7,1 & 11,0 \\
\hline other & 1,7 & 5,9 & 4,7 \\
\hline Total & 100,0 & 100,0 & 100,0
\end{tabular}

Table 5: Sending remittances to accomplish their own goals (e.g. house renovation) by ethnicity (\%)

\begin{tabular}{c|c|c|c} 
& non-Roma & Roma & Total \\
\hline & $\mathrm{N}=190$ & $\mathrm{~N}=452$ & $\mathrm{~N}=642$ \\
\hline no & 64,7 & 55,8 & 58,4 \\
\hline yes & 35,3 & 44,3 & 41,6 \\
\hline Total & 100,0 & 100,0 & 100,0
\end{tabular}

Table 6: Sending remittances to family members by ethnicity (\%)

\begin{tabular}{c|c|c|c} 
& non-Roma & Roma & Total \\
\hline & $\mathrm{N}=190$ & $\mathrm{~N}=452$ & $\mathrm{~N}=642$ \\
\hline no & 60,0 & 69,2 & 66,5 \\
\hline yes & 40,0 & 30,8 & 33,5 \\
\hline Total & 100,0 & 100,0 & 100,0
\end{tabular}


Table 7: Sending remittances to pay debts by ethnicity (\%)

\begin{tabular}{c|c|c|c} 
& non-Roma & Roma & Total \\
\hline & $\mathrm{N}=190$ & $\mathrm{~N}=452$ & $\mathrm{~N}=642$ \\
\hline no & 91,1 & 82,1 & 84,7 \\
\hline yes & 8,9 & 17,9 & 15,3 \\
\hline Total & 100,0 & 100,0 & 100,0
\end{tabular}

\section{References}

Acuna, E. (2016): Romani Mobilities as Resilience Strategies: Trans-Atlantic Expectations, Lives and Journey. Timisoara, Romania: Paper presented to the Second World Congress on Resilience: From Person to Society.

Appadurai, A. (2004): The capacity to aspire: culture and the terms of recognition. In Rao, V. - Walton, M. (eds.): Culture and Public Action. Washington, DC: The World Bank, 59-84. Anghel, R. G. (2016): "Migration in Differentiated Localities: Changing Statuses and Ethnic Relations in a Multi-Ethnic Locality in Transylvania, Romania." Population, Space and Place 22 (4): 356-366. DOI:10.1002/psp.1925.

Bauman, Z. (2004): Wasted Lives. Modernity and its Outcasts. Cambridge: Polity Press Blaskó, Zs. - Gödri, I. (2014): Kivándorlás Magyarországról: szelekció, célországválasztás az „új migránsok” körében. Demográfia, 54 (4): 271-307.

Blaskó, Zs. - Gödri, I. (2016): A Magyarországról kivándorlók társadalmi és demográfiai összetétele. In: Blaskó, Zs. - Fazekas, K. (szerk.): Munkaerôpiaci tükör 2015. Budapest: MTA Közgazdaság- és Regionális Tudományi Kutatóközpont Közgazdaság-Tudományi Intézet, 59-67.

Bosch Media Service (2017): Bosch celebrates fifteen years in Miskolc. https://www. boschmediaservice.hu/en/press/release/bosch-celebrates-fifteen-years-in-miskolc-26.html

Butler, J. (2004): Undoing gender. London - New York: Routledge

Castles, S. (2010): Understanding global migration: a social transformation perspective. Journal of Ethnic and Migration Studies 30 (10): 1565-1586. DOI: https://doi.org/10.1080/1369183x.2010.489381

Castles, S. - Miller, M. (2009): The Age of Migration: International Population Movements in the Modern World (4 ${ }^{\text {th }}$ edition). Basingstoke: Palgrave Macmillan. DOI: https:// doi.org/10.1007/978-1-349-26846-7

Castree, N. - Coe, N. - Ward, K. - Samers, M. (2004): Spaces of work: global capitalism and geographies of labour. London: Thousand Oaks/New Delhi: Sage

Ciaschi, P. (2018): Around and Around: The Politics of Mobility in Everyday Lives of Roma in Current Day Hungary. Intersections, EEJSP, 4 (3):17-36.

Ciupijus, Z. (2011): Mobile Central Eastern Europeans in Britain: Successful European Union Citizens and Disadvantaged Labour Migrants? Work, Employment and Society, 25 (3): 540-550. DOI: https://doi.org/10.1177/0950017011407962 
Clave-Mercier, A. - Olivera, M. (2018): Inclusion and the 'Arts of Resistance'. How do Roma Migrants Develop Autonomy in the Context of Policies? Intersections. EEJSP, 4 (3): 149-168. Copestake, J. - Camfield, L. (2010): Measuring multidimensional aspirations gaps: a means to understanding cultural aspects of poverty. Development Policy Review, 28 (5): 617-633.

Czakó, Á. - Sik, E. (2003): The Role of the Network as a Resource in Economic Transactions in Post-Communism. In: Mendell, M. - Nielsen, K. (eds): Europe. Central and East. Montreal-New York - London: Black Rose Books, 224-247.

De Haas, H. (2005): International Migration: Remittances and Development: myths and facts. Third World Quaterly, 26 (8): 1269-1284.

De Haas, H. (2008): Migration and Development: A Theoretical Perspective. International Migration Institute, Working Papers, Paper 9.

De Haas, H. (2010): The Internal Dynamics of Migration Processes: A Theoretical Inquery. Journal of Ethnic and Migration Studies, 36 (10): 1587-1617. DOI: http:// dx.doi.org/10.1080/1369183X.2010.489361

De Haas, H. (2014): Migration Theory. Quo Vadis? IMI Working Papers, No. 100, International Migration Institute, University of Oxford. https://www.imi.ox.ac. uk/publications/wp-100-14

Delgado Wise, R. - Covarrubias, H. M. (2009): Understanding the Relationship Between Migration and Development. Toward a New Theoretical Perspective. Social Analysis, 53 (3): 85-105.

Durst, J. (2013): 'It is better to be a Gypsy in Canada than being a Hungarian in Hungary': The 'New Wave' of Roma Migration. In Vidra, Zs. (ed.): Roma Migration to and from Canada. The Czech, Hungarian and Slovak Case. Center for Policy Studies Central European University, 203-248.

Durst, J. (2018): Out of the Frying Pan into the Fire? From Municipal Lords to the Global Assembly Lines - Roma's Experiences of Social (Im)mobility Through Migration From North Hungary. Intersections EEJSP 4 (3): 4-28.

Durst, J. - Nagy, V. (2018): Transnational Roma Mobilities: The Enactment of Invisible Resistance. Intersections EEJSP 4 (2): 3-16.

Durst, J. - Nyírő, Zs. (2019): The role of kinship ties in migration. Ethnic differences in transnational mobility in North Hungary. Forthcoming.

Emirbayer, M. - Mische, A. (1998): What Is Agency? American Journal of Sociology. 103 (4): 962-1023.

Enright, B. (2013): (Re)Considering New Agents: A Review of Labour Market Intermediaries within Labour Geography. Geography Compass, 7 (4): 287-299. DOI: https://doi.org/10.1111/gec3.12035

Faist, T. (2008): Migrants as Transnational Development Agents: An Inquiry into the Newest Round of the Migration-Development Nexus. Population, Space and Place 14 (1): 21-42.

Faist, T. (2009): Transnationalization and Development. Toward an Alternative Agenda. Social Analysis, 53(3): 38-59. 
Faist, T. (2016): Social Mechanisms in Local Transformations: Towards a Conclusion. Population, Space and Place, 22 (4): 356-366. DOI: 10.1002/psp.1927

Glick Schiller, N. - Basch, L. - Blanc-Szanton, C. (1991): Towards a transnational perspective on migration. New York: New York Academy of Science

Glick Schiller, N. (2009): A Global Perspective on Migration and Development. Social Analysis, 53 (3): 14-37.

Glick Schiller, N. - Faist, T. (2009): Introduction. Migration, Development and Social Transformation. Social Analysis, 53(3): 1-13.

Glick Schiller, N. - Salazar, N. B. (2013): Regimes of Mobility Across the Globe. Journal of Ethnic and Migration Studies 39 (2): 183-200.

Greenfields, M. - Dagilyte, E. (2018): 'I would never have come if we'd know it might be like this': On the (un)intended consequences of welfare governance of EU Roma migrants in Britain. Intersections. EEJSP, 4(3): 81-105.

Grigolini, S. (2005): When houses provide more than shelter: analysing the uses of remittances within thier sociocultural context. In: Trager, L. (ed): Migration and Economy: Global and Local Dynamics. Lanham/Oxford: Altimara Press/ Society for Economic Anthropology: 193- 223.

Grill, J. (2017): 'In England, They Don't Call You Black!' Migrating Racialisations and the Production of Roma Difference Across Europe. Journal of Ethnic and Migration Studies, 44(7): 1136-1155. DOI: https://doi.org/10.1080/136918 3X.2017.1329007

Guarnizo, L. - Portes, A. - Haller, W. (2003): Assimilation and transnationalism: determinants of transnational political action among contemporary migrants. American Journal of Sociology, 108 (6): 1211-1248.

Guy, W. (2003): „No Soft Touch”: Romani Migration to the UK at the Turn of the Twenty-first Century. Nationalities Papers. The Jornal of Nationalism and Ethnicity, 31(1): 63-79.

Harney, N. (2006): Rumour, migrants, and the informal economy of Naples, Italy. International Journal of Sociology and Social Policy, 26(9/10): 374- 384.

Hárs, Á. (2016): Nemzetközi vándorlás, migrációs válság. In: Kolosi, T. - Tóth, I. Gy. (szerk.): Társadalmi Riport 2016, TÁRKI, 351-372.

Hárs, Á. (2018): Növekvő elvándorlás - lehetőségek, remények, munkaerőpiaci hatások. In: Kolosi, T. - Tóth, I. Gy. (szerk.): Társadalmi Riport 2018, TÁRKI, 81- 105.

Horváth, I. - Kiss, T. (2015): Depopulation Semi-Peripehry? Longer Term Dynamics of Migration and Socioeconomic Development in Romania. Demográfia, 58 (5): 91-132. English Edition DOI:10.21543/DEE.205.4

Horváth, K. (2012): 'Silencing and naming the difference'. In Stewart, M. (ed.): Gypsy 'Menace'. Populism and the new anti-Gypsy politics. London: Hurst \& Company: 117- 135.

Humphris, R. (2017): On the threshold: becoming Romanian Roma, everyday racism and residency rights in transition. Social Identities: Journal for the Study of Race, Nation and Culture. DOI: https://doi.org/10.1080/13504630.2017.1335831 
Ibrahim, S. (2011): Poverty, aspirations and well-being: afraid to aspire and unable to reach a better life - voices from Egypt. BWPI Working Paper 141.

Kandel, W. - Massey, D.S. (2012): The Culture of Mexican Migration: A Theoretical and Empirical Analysis. Social Forces, 80 (3): 981-1004.

Kapur, D. (2004): Remittances: The New Development Mantra? G-24 Discussion Paper Series No.29., New York and Geneva: United Nations

Kertesi, G. (2005): A társadalom peremén. Romák a munkaerőpiacon és az iskolában. Budapest: Osiris

Kothari, U. (2002): Migration and chronic poverty. Institute for Development Policy and Management, University of Manchester. Chronic Poverty Research Centre. Working Paper No 16.

Kovai, C. (2017): A cigány-magyar különbségtétel és a rokonság. Budapest: L’Harmattan Kováts, A. (szerk.) (2002): Roma Migráció. Budapest: MTA Kisebbségkutató IntézetNemzetközi Migrációs és Menekültügyi Kutatóközpont

Kóczé, A. (2017): Race, Migration and Neoliberalism: Distorted Notions of Romani Migration in European Public Discourses. Social Identities, 24 (4): 459-473. DOI: https://doi.org/10.1080/13504630.2017.1335827

Ladányi, J. - Szelényi, I. (2004): A kirekesztettség változó formái. Napvilág Kiadó.

Leggio, D. V. - Matras, Y. (2018): How open borders can unlock cultures: concepts, methods, and procedures. In Matras, Y. - Leggio, D. V. (eds): Open borders, Unlocked Cultures. Romanian Roma Migrants in Western Europe. London and New York: Routledge:1-25.

Levine-Rasky, C. (2016): 'They Didn't Treat Me as a Gypsy': Romani Refugees in Toronto. Refuge, 32(3): 54-62.

Levitt, P. (1998): Social remittances: migration driven local-level forms of cultural diffusion. International Migration Review, 32 (4): 926-948.

Limmer, R. - Collet, B. - Ruppenthal, S. (2010): Introduction: Job-Related Spatial Mobility in Contemporary European Societies. In: Schneider, N. F. - Collet, B. (eds.): Mobile Living Across Europe II: Causes and Consequences of Job-Related Spatial Mobility in Cross-National Comparison. Opladen-Farmington Hills, MI: Barbara Budrich Publishers. 15-24.

MacDonald, R. (1994): Fiddle Jobs, Undeclared Working, and the Something for Nothing Society. Work, Employment, and Society, 8 (4): 507-530. DOI: https://doi. org/10.1177/095001709484002

Melegh,A. - Sárosi, A. (2015): Magyarország bekapcsolódása a migrációs folyamatokba: történeti-strukturális megközelítés. Demográfia 58 (4): 221-265. DOI: http:// dx.doi.org/10.21543/DEM.58.4.1

Melegh, A. - Gábriel, D. - Gresits, G. - Háros, D. (2018): Abandoned working classes and the political economy of elderly care work in Hungary. Forthcoming: Review of Sociology of the Hungarian Sociological Association 28(4): 61-88.

Moreh, C. (2014): Hungarian post-accession mobility to the UK. Demográfia, 57(4): 79- 104. Nagy, V. - Oude-Breuil, B. C. (2015): Mobility Rules: Migrants and Drifters Fare Well (?) in Post-Welfare Europe. In: de Jong, F. (ed.) Overarching Views of Crime and Deviance. The Hague: Eleven. 527-546. 
Nagy, V. (2016): The Welfare Ban-opticon: Financial Sorting of Low-income Migrants from Central and Eastern Europe. Review of Sociology, (26) 4: 75-96.

Nagy, V. (2018): The Janus face of precarity. Securitisation of Roma mobility in the UK. Local Economy, 33(2): 127-146

Narotzky, S. - Besnier, N. (2014): Crisis, value, and Hope: Rethinking the economy: An Introduction to Supplement 9. Current Anthropology, 55 (S9): S4-S16

Németh, K. - Váradi, M. M. (2018): Development in the Context of Care Migration from Rural Hungary: An agency-based approach. Forthcoming: Review of Sociology of the Hungarian Sociological Association 28(4): 88-111.

Pantea, M.-C. (2013): "Social Ties at Work: Roma Migrants and the Community Dynamics". Ethnic and Racial Studies, 36 (11): 1726-44.

Pine, F. (2014): Migration as Hope: Space, Time, and Imagining the Future. Current Anthropology, 55(S9): S95-S104. DOI: https://doi.org/10.1086/676526

Piore, M. J. (1979): Birds of passage: Migrant labor in industrial societies. New York: Cambridge University Press.

Portes, A. (2010): The Informal Economy. In: Portes, A.: Economic Sociology. A Systematic Inquiry. Princeton and Oxford: Princeton University Press: 130-161.

Portes, A. (2013): Migration and Development. Reconciling Opposite Views. In: Eckstein, Susan Eva - Najam, Adil (ed.): How Immigrants Impact Their Homelands. Durham: Duke Univeristy Press, 30-51.

Ray, D. (2006): Aspirations, poverty and economic change. In: Banerjee, A. V. - Bénabou, R. - Mookherjee, D. (eds.): Understanding Poverty. Oxford: Oxford University Press.

Robertson, R. - White, K.E. (2007): What is Globalization? In: Ritzer, G. (ed): The Blackwell Companion to Globalization. Malden: Blackwell Publishing: 54-66.

Rogaly, B. (2009): Spaces of work and everyday life: labour geographies and the agency of unorganised temporary migrant workers. Geography Compass, 3 (6):1749-1771.

Sardelic, J. (2017): In and Out From the European Margins: Reshuffling Mobilities and Legal Statuses of Romani Minorities Between the Post-Jugoslav Space and the European Union. Social Identities, 24 (4): 489-504. DOI: https://doi.org/10.18 0/13504630.2017.1335829

Sen, A. (1999): Development as Freedom. Oxford: Oxford University Press.

Sik, E. (2013): “A magyar társadalom megérett a migrációra”. Rádai Eszter interjúja. Élet és Irodalom 2013. aug. 16

Sik, E. - Szeitl, B. (2015): Quasi-diaspora and Cross-border Diaspora in the HungarianSlovak-Ukrainian Triborder Region. Review of Sociology, 25 (4): 107- 125.

Skeldon, R. (1997): Migration and development: a global perspective. Essex: Longman

Stack, C. (1974): All our kin. New York: Basic Books

Szabó, Á. T. (2018): "Local and Global Contexts, Individual Experiences in Labour: Poor Roma at Home and Abroad. A Case from Transylvania, Romania." Local Economy: The Journal of the Local Economy Policy Unit 33 (2): 207-23. DOI:10.1177/0269094218762345. 
Tesar, C. (2016): Houses under Construction: Conspicuous Consumption and the Values of Youth among Romanian Cortorari Gypsies. In Brazzabeni, M. - Cunha, M. I. - Fotta, M. (eds.): Gypsy Economy. Romani Livelihoods and Notions of Worth in the 21st Century. New York - Oxford: Berghahn Books, 181-200.

Toma, S. - Tesăr, C. - Fosztó, L. (2017): Romanian Roma at home: mobility patterns, migration experiences, networks, and remittances. In: Matras, Yaron - Leggio, Daniele Viktor (ed.): Open Borders, Unlocked Cultures. Romainan Roma Migrants in Western Europe. London -New York: Routlegde, 57-82.

Tremlett, A. - Messing, V. - Kóczé, A. (2017): Romaphobia and the Media: Mechanisms of Power and the Politics of Representations. Identities. Global Studies in Culture and Power, 24 (6): 641-649.

Van Baar, H. (2017): Contained mobility and the racialization of poverty in Europe: the Roma at the development-security nexus. Social Identities, 24 (4): 1-17. DOI: https://doi.org/10.1080/13504630.2017.1335826

Váradi, M. M. (2016): Mennek, maradnak, visszajönnek. In Sikos T. T. - Tiner, T. (szerk.): Tájak, régiók, települések térben és idöben. Tanulmánykötet Beluszky Pál 80. születésnapjára. Budapest: Dialóg Campus, 461-472.

Váradi, M.M. - Durst, J. - Fehér, K. - Németh, K. - Virág, T. (2017): Kényszerü mobilitás: migrációs utak hátrányos helyzetű vidéki terekben. socio.hu 7 (3): 2546. DOI: 10.18030/SOCIO. HU. 2017.3.25

Váradi, M. M. (2018): Migráció alulnézetból. Budapest: Argumentum

Venkatesh, S. A. (2006): Off the Books. The Underground Economy of the Urban Poor. Cambridge - London: Harvard University Press.

Vertovec, S. (1999): Conceiving and researching transnationalism. Ethnic and Racial Studies, 22 (2): 445-462.

Vidra, Zs. (2013): Roma Migration To and From Canada: The Czech, Hungarian, and Slovak Case. Budapest: Center for Policy Studies, Central European University.

Vidra, Zs. - Virág, T. (2013): Some Hypotheses and Questions on the New Wave of Hungarian Roma Migration to and From Canada. In Vidra, Zs.(ed.): Roma Migration to and from Canada: Czech, Hungarian and Slovak Case. Budapest: Center for Policy Studies.

Virág, T. (2018): A kapcsolathálózatok szerepe a migrációban egy cigányfalu perspektívájából. Különszám Szalai Júlia köszöntésére. Szerk.: Messing, V. - Neményi, Mária - Szikra D.. socio.hu 8 (1): 163-179. DOI:10.18030/SOCIO. HU.2018.1.163

Wallerstein, I. (1980): The Modern World System II, Mercantilism and the Consolidation of the European World-Economy, 1600-1750. New York: Academic Press.

Widmer, E.D. - Viry, G. - Kaufmann, V. (2010): The Process of Becoming Mobile. In: Schneider, N.F. - Collet, B. (eds.): Mobile Living Across Europe II. Opladen \& Farmington Hills, MI: Barbara Budrich Publishers: 113-129.

Yildız, C. - De Genova, N. (2017): Un/Free Mobility: Roma Migrants in the European Union. Social Identities, 24 (4): 1-17. DOI: https://doi.org/10.1080/13504630.201 7.1335819 